\title{
DIE WERKSGESKIEDENIS VAN OUDSTUDENTE VAN DIE DEPARTEMENT VERPLEEGKUNDE AAN DIE UNIVERSITEIT VAN DIE ORANJE VRYSTAAT
}

Leana R. Uys

\section{INLEIDING}

In 1986 was die Departement

Verpleegkunde aan die Universiteit van die Oranje Vrystaat 17 jaar oud, en die aadkursus in verpleegkunde 23 jaar oud. e was ook die laaste jaar wat die geîntegreerde Diploma in Verpleegkunde, 'n baie populêre program wat in 1970 daar ingestel is, nog in die jaarboek verskyn het. Om hierdie tydperk paslik te herdenk, is ' $n$ reünie van oudstudente van die

Departement gehou. Hierdie poging om oudstudente op te spoor is as 'n gulde geleentheid beskou om vas te stel hoe die produkte van beide die B. Soc. Sc.

Honneurs (Verpleegkunde) en die Diploma in Verpleegkunde hul na hul opleiding besig gehou het.

\section{METODE}

'n Vraelys is opgestel wat die volgende aspekte gedek het:

1. Periode van werk.

2. Verdere studie na opleiding.

3. Landstreek(e) werksaam.

4. Werkgewer(s).

5. Posbenaming(s).

Tipe werk.

Die vraelys was ten opsigte van elk van hierdie aspekte in kategorieë verdeel en die respondent moes elke pos wat sy/hy beklee het, ten opsigte van aspekte twee tot vyf kategoriseer.

Die vraelys is deur 'n partuurgroep nagegaan vir volledigheid en verstaanbaarheid. Daarna is dit na ongeveer 1000 afgestudeerdes gestuur volgens die adresse wat in die Universiteit se besit was. Almal is ingesluit omdat die adresse dikwels oud was en daar dus verwag is om slegs ' $n$ klein persentasie terug te ontvang.

Ongeveer 340 vraelyste is terug ontvang, waarvan sommige nie gebruik kon word nie omdat dit onvolledig ingevul is. 'n Totaal van 327 vraelyste kon wel gebruik word. Dit is 'n swak realisasie van die groep, maar daar is besluit om voort te gaan met die analise van die data omdat dit nog 33\% van die populasie uitmaak en ' $n$ beter realisasie onwaarskynlik is.

\section{RESULTATE}

Van die 327 vraelyste wat gebruik is, was

\section{Samevatting}

In 1986 is 'n opname van 327

oudstudente van die Departement

Verpleegkunde aan die Universiteit van die Oranje Vrystaat gedoen. 'n Vraelys is na alle graduandi en diplomandi gestuur en het die volgende aspekte gedek; waar en as wat het hul gewerk na hul opleiding, wie hul werkgewers was, hoe lank hulle gewerk het en watter verdere opleiding hulle ondergaan het. Daar is gevind dat oudstudente baie aktief was in die beroep, met 'n langdurige werksrekord in baie tipes dienste en oor die hele land.

\section{Summary}

In 1986, a survey of 327 ex-students of the Department of Nursing at the University of the Orange Free State was done. A questionnaire covering the following aspects was sent to all graduates and diplomates: where and in what capacity they worked after their training, who their employers were, how long they worked and which further training they have had. It was found that these ex-students were very active in the profession, with a long service record in many types of services across the country.

130 afkomstig van B. Soc. Sc. Honneurs (Verpleegkunde) graduandi en 197 van persone in besit van die Diploma in Verpleegkunde.

\section{WERKSPERIODE}

In Tabel 1 word die jare wat graduandi sedert hul opleiding kon gewerk het, (beskikbaar jare) vergelyk met die aantal jare wat hul wel in verpleging gewerk het.

Oorhoofs het graduandi $60,4 \%$ van die beskikbare tyd gewerk. Die enigste groep wie se persentasie onder $60 \% \mathrm{val}$, is die groep wat 16 tot 18 jaar gelede hul opleiding voltooi het.

In Tabel 2 word dieselfde gegewens ten opsigte van diplomandi gegee. Hulle het gemiddeld $69,2 \%$ van die beskikbare tyd gewerk, met besonder hoë persentasie in die eerste ses jaar na opleiding (78\%). Dit is besonder hoog vir daardie ouderdomsgroep ( \pm 22 tot 28 jaar) in 'n vroueberoep.

Die verskil tussen graduandi en diplomandi is beduidend. Die chikwadraat toon dat daar net 'n $3,9 \%$ kans is dat hierdie verskil toevallig is.

VERDERE STUDIE NA OPLEIDING In Tabel 3 word die verdere studie wat die oudstudente onderneem het, uiteengesit. Uit die tabel blyk dit dat ' $n$ groter persentasie van die graduandi as die diplomandi verder studeer het $\mathbf{5 8 , 5 \%}$ teenoor $41,1 \%$ ). Meer van hulle gaan ook in vir Verpleegopleiding en

Verpleegadministrasie (13\% teenoor 5\%). Wat die groter persentasie kliniese kursusse onder die diplomandi betref, moet onthou word dat die meeste van die Meestersgrade van die graduandi klinies van aard was.

In die lig van die tekort aan verpleegkundiges met addisionele kwalifikasies (Kotze, 1987, p. 9), is die 


\begin{tabular}{|c|c|c|c|c|c|c|c|c|}
\hline \multicolumn{9}{|c|}{ TABEL, 2. WERKSJARE VAN DIPLOMMANDI } \\
\hline \multirow[b]{2}{*}{$\begin{array}{c}\text { Jare na } \\
\text { opleiding }\end{array}$} & \multicolumn{3}{|c|}{ Beskikbare jare na opleiding } & \multicolumn{3}{|c|}{ Jare gewerk na opleiding } & \multirow[b]{2}{*}{$\begin{array}{c}\mathrm{X} \text { jare } \\
\text { gewerk }\end{array}$} & \multirow{2}{*}{$\begin{array}{c}\text { Xovan } \\
\text { moontlike } \\
\text { jare }\end{array}$} \\
\hline & I persone & \% persone & $\begin{array}{l}\text { kum } \% \\
\text { persione }\end{array}$ & I persone & To persone & $\begin{array}{l}\text { kum \% } \\
\text { persone }\end{array}$ & & \\
\hline $16-18$ & 3 & 2 & 100 & 0 & - & - & 11,3 & 69,4 \\
\hline $13-15$ & 12 & 6 & 98 & 5 & 3 & 100 & 7,8 & 57 \\
\hline $10 \cdot 12$ & 31 & 16 & 92 & 12 & 6 & 97 & 6,8 & 62,7 \\
\hline 7.9 & 56 & 28 & 76 & 36 & 18 & 91 & 5,3 & 69,8 \\
\hline 4-6 & 63 & 32 & 48 & 63 & 32 & 73 & 3.8 & 76.7 \\
\hline & 32 & 16 & 16 & 81 & 41 & 41 & 1,6 & 79.7 \\
\hline Totanl & 197 & 100 & 100 & 197 & 100 & 100 & & $\overline{\mathrm{x}}=69,2$ \\
\hline
\end{tabular}
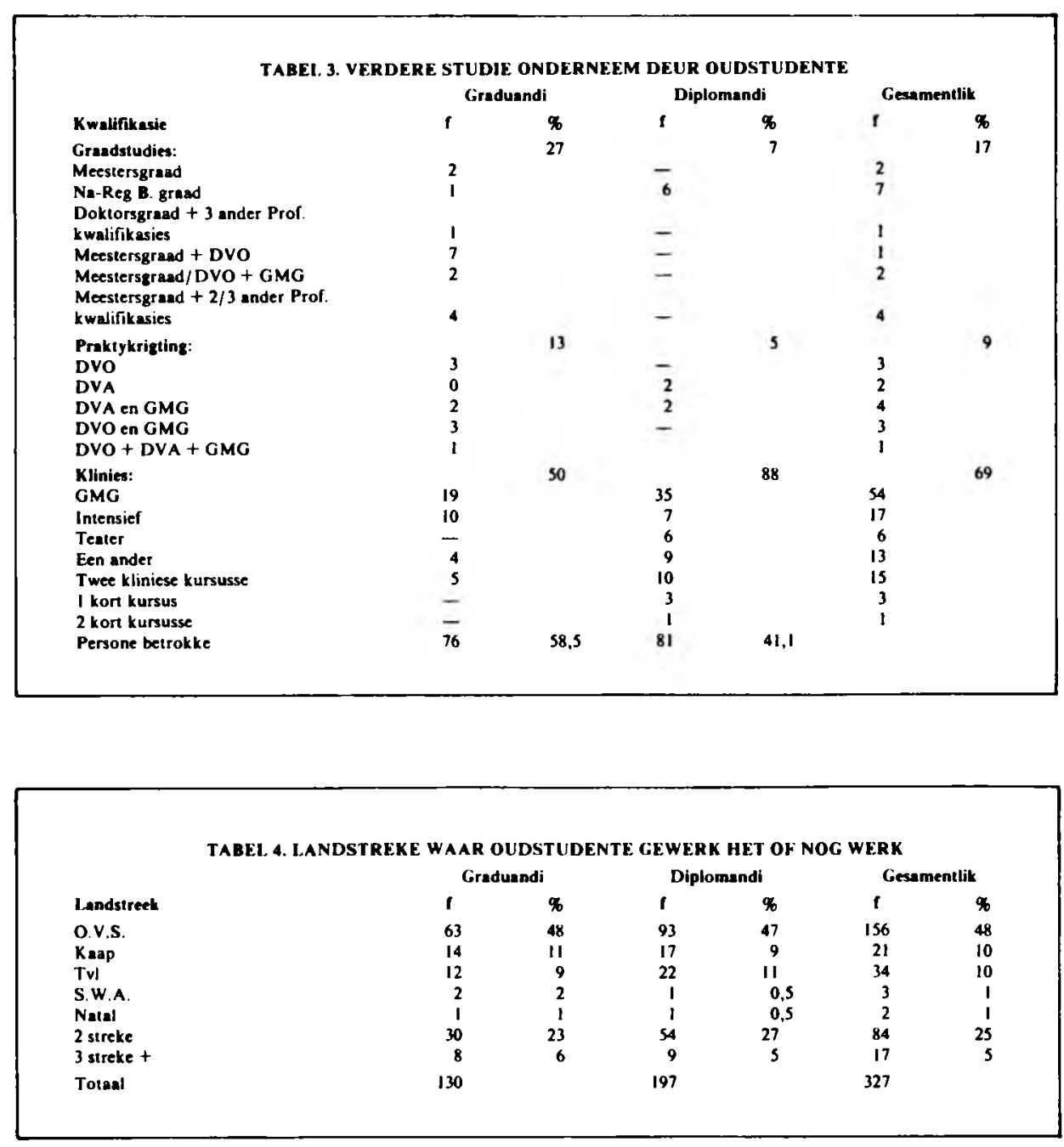

\begin{tabular}{|c|c|c|c|c|c|c|}
\hline \multirow[b]{3}{*}{ Werkgewer } & \multicolumn{4}{|c|}{ TABEL. S. WER KGEWERS VAN OUDSTUDENTE } & & \\
\hline & \multicolumn{2}{|c|}{ Graduandi } & \multicolumn{2}{|c|}{ Diplomandi } & \multicolumn{2}{|c|}{ Geasmentiii: } \\
\hline & Aantal & $\%$ & Aantal & $\%$ & Aantal & क \\
\hline \multicolumn{7}{|l|}{ Een tipe alleen: } \\
\hline Provinsie & 60 & 46 & 85 & 43 & 145 & 44 \\
\hline Stantsgesondheid & 2 & 1 & 5 & 2 & 7 & 1 \\
\hline Plaaslike owerheid & 4 & 3 & 6 & 2 & 10 & 2 \\
\hline Privant Org. & 3 & 2 & 17 & 9 & 20 & 6 \\
\hline Universiteit & 2 & 2 & 0 & 0 & 2 & 1 \\
\hline Weermag & 1 & 1 & 2 & 1 & 3 & 1 \\
\hline Welsynsorg & 2 & 2 & 3 & 1 & $\mathbf{5}$ & I \\
\hline Self & I & $\mathbf{I}$ & 0 & 0 & 1 & $\mathbf{I}$ \\
\hline Gevangenisdiens & 1 & I & 0 & $\mathbf{0}$ & $i$ & I \\
\hline \multicolumn{7}{|l|}{ Kombinasie van twee: } \\
\hline Provinsie/Staat & 9 & 7 & 13 & 7 & 22 & $?$ \\
\hline Provinsie/privaat & 8 & 6 & 15 & 8 & 23 & 7 \\
\hline Provinsie/Weermag & 3 & 2 & 4 & 2 & 7 & 2 \\
\hline Provinsie/PI owerheid & 6 & 5 & 7 & 4 & 13 & 5 \\
\hline Provinsie/ universiteit & 9 & $?$ & 4 & 2 & 13 & 4 \\
\hline Ander & 13 & 10 & 17 & 9 & 30 & 10 \\
\hline \multicolumn{7}{|c|}{ Kombinasies van drie of meer: } \\
\hline & 6 & $\mathbf{s}$ & 19 & 10 & 25 & 7 \\
\hline Totad & 130 & & 197 & & 327 & 100 \\
\hline
\end{tabular}

graduandi dus 'n waardevolle kragbron vir die beroep. Ongeveer vyf graduandi het grade in ander rigtings voltooi byvoorbeeld sielkunde, onderwys, wet en handel.

\section{LANDSTREEK(E) WERKSAAM}

Uit hierdie tabel (Tabel 4) is dit duidelik dat die Oranje Vrystaat ongeveer die helfte van die studente wat daar opgelei word, behou (48\%). As die persone wat in die Vrystaat sowel as in ander streke gewerk het, in aanmerking geneem word, is die persentasie so hoog as $75 \%$.

Verder kry die Kaap Provinsie en Transvaal baie aftrek ( $10 \%$ elk) en kombinasies van die Vrystaat met elk van hierdie provinsies is ook baie populêr. ( $11 \%$ en $7 \%$ onderskeidelik)

\section{WERKGEWERS}

Uit Tabel 5 blyk die dat $59 \%$ van die oudstudente hul hele loopbaan vir een tipe owerheid werk, alhoewel hulle binne die kategorie mag rondskuif, bv. van een provinsiale owerheid na 'n ander.

Die patroon van graduandi en diplomandi is baie dieselfde, behalwe vir die groter hoeveelheid graduandi wat vir universiteite werk en die groter hoeveelheid diplomandi wat vir privaat organisasies werk.

\section{POSBENAMINGS}

In 'n poging om vas te stel tot hoeverre oudstudente op die beroepsleer gevorder het, is die posbenaming van elke pos wat hulle bekleer het, gevra. In Tabel 6 word die hoogste pos wat elke oudstudent bereik het, aangedui. Dit is interessant dat soveel as $78 \%$ van die groep nog steeds op die laagste rang, "verpleegkundige", is. Dit beteken nie noodwendig dat hulle nooit bevordering gekry het nie, want baie staan in dienste wat die posbenaming nie 'n indikasie van die inkomste is nie, en waar die Kommissie vir Administrasie se posbenamings nie gebruik word nie.

Verder is dit interessant dat slegs graduandi op die vierde en vyfde trap van die leer gekom het. Die gemiddelde tydperk wat elke poskategorie se bekleërs in diens is, toon dat graduandi gemiddeld die helfte van die tyd neem om op die derde trap te kom as wat diplomandi neem.

Die chi-kwadraat toon dat die verskil in rang tussen diplomandi en graduandi ten opsigte van die rang wat bereik word, sowel die tyd wat dit neem om dit te bereik, beduidend is $(, 2786$ ten opsigte van rang en , 1558 ten opsigte van tyd).

\section{TIPE WERK}

Dit was onmoontlik om die tipe werk wat die oudstudente gedoen het en nog doen, in tabelvorm op te som.

Soos verwag kan word aangesien die provinsiale administrasies die grootste gros in diens neem, is die meeste in akademiese of opleidingshospitale werksaam.

Plattelandse hospitale is ook 'n baie algemene werksplek. 


\begin{tabular}{|c|c|c|c|c|c|c|c|c|}
\hline \multicolumn{9}{|c|}{ TABEI. 6. HOOGSTE POS DEUR ELKE OUDSTUDENT REKI.EE } \\
\hline \multirow[b]{2}{*}{ Rang } & \multicolumn{2}{|c|}{ Graduandi } & \multicolumn{2}{|c|}{ Diplomandi } & \multicolumn{2}{|c|}{ Getnmentile } & \multirow{2}{*}{$\begin{array}{l}\text { Grand } \\
x \text { jare } \\
\text { dlens }\end{array}$} & \multirow{2}{*}{$\begin{array}{l}\text { Dipl. } \\
\text { X jare } \\
\text { diens }\end{array}$} \\
\hline & I & \% & I & $\%$ & $\mathbf{1}$ & $\%$ & & \\
\hline $\begin{array}{l}\text { Suster/verpleegkundige } \\
\text { Senior suster/senior verpl./ matrone/ } \\
\text { dosent }\end{array}$ & $\begin{array}{r}101 \\
24\end{array}$ & $\begin{array}{l}78 \\
18\end{array}$ & 155 & 79 & 256 & 78 & 7,3 & 8,6 \\
\hline $\begin{array}{l}\text { Senior matrone / hoof verpl. / senior } \\
\text { dosent }\end{array}$ & 2 & 1.5 & 4 & 2 & 6 & 2 & 5,5 & 10,8 \\
\hline $\begin{array}{l}\text { Eerste matrone/hoof verp] } \\
\text { diensbestuurder/senior prinsipale }\end{array}$ & 2 & 1,5 & - & - & 2 & 1 & 11 & $\mathbf{0}$ \\
\hline Hoofmatrone/senior verpl. diensbest. & 1 & 1 & & & 1 & 1 & 8 & $\mathbf{0}$ \\
\hline & 130 & 100 & 197 & 100 & & 100 & & \\
\hline
\end{tabular}

Baie dikwels spreek die werkspatroon van ' $n$ persoon wat in 'n akademiese en/of opleidingshospitaal gewerk het totdat sy getroud is en na 'n klein plekkie getrek het. Daar doen sy enigiets van distriksgeneesheerskantoor, snipperpos by Gesinsbeplanning, dokterspreekkamer, trisverpleging, kliniek tot ouetehuis. ie patroon van die graduandi en diplomandi verskil net ten opsigte van die groter betrokkenheid van diplomandi by dokterspreekkamers en private instansies.

\section{GEVOLGTREKKINGS EN SLOT}

As gevolg van die beperkings van die steekproef moet die gegewens baie versigtig hanteer word. Tog wil dit voorkom asof die oudstudente van hierdie opleidingskool tot 'n hoë mate die diens lewer waarvoor hul opgelei is. Dit lyk asof graduandi meer geneig is om verder te studeer en vinniger verder kom op die beroepsieer. Dit beteken egter nie dat diplomandi ver agteruitstaan nie; hul studeer en vorder ook en lewer persentasie-gewys meer diens.

Die studie behoort herhaal te word om die gegewens te kontroleer en soortgelyke studies behoort deur ander opleidingskole aangepak te word om mannekrag en opleidingsbeplanning te bevorder.

\section{BIBLIOGRAFIE}

Kotze W.J. Tendense in die Verpleegberoep: Aspekte vir Oorweging; 1987. Curationis 10(4): 4-10.

L.R. Uys, D.Soc. Sc. (Nursing), G.V., G.V.V., G.P., D.U.O. D.H.A. Professor en Hoof Depi Verpleegkunde Universiteit van Natal 